\title{
POSSIBLE ADAPTATION OF PUBLIC UTILITY CONCEPTS IN THE HEALTH CARE FIELD
}

\author{
A. J. G. PrIEST*
}

If charges made by hospitals and like institutions are to be determined by governmental agencies, what regulatory analogy should be applied? What segments of the economy most closely resemble the health care industry? Would the Supreme Court sustain legislation that authorizes administrative price fixing in the field of health care?

The last of these questions can be answered "Yes" without hesitation. The Court has uniformly approved price fixing legislation since the early New Deal, and it cannot be expected to reverse forty years of consistent holdings, even with recent and impending changes in its membership. Decisions sustaining the propriety of legislation that authorizes the strict regulation of public utilities could be cited in profusion, and there have been no recent and significant Supreme Court exceptions. For example, in I934 the Court upheld a New York statute which established a milk control board with power to fix maximum and minimum retail prices. Mr. Justice Roberts, speaking for the majority, said that the fifth and fourteenth amendments

do not prohibit governmental regulation for the public welfare. They merely condition the exertion of the admitted power, by securing that the end shall be accomplished by methods consistent with due process. And the guaranty of due process ... demands only that the law shall not be unreasonable, arbitrary or capricious, and that the means selected shall have a real and substantial relation to the object sought to be attained.

-...

... [T] here can be no doubt that upon proper occasion and by appropriate measures the state may regulate a business in any of its aspects, including the prices to be charged for the products or commodities it sells. ${ }^{1}$

The Court declared in I930 and again in 1936 that charges for stockyard services may properly be determined by a federal agency; the fixing of maximum prices for bituminous coal was approved in $1940 ;^{2}$ and any lingering doubts were dissipated in I94r by a unanimous decision which upheld the constitutionality of a Nebraska statute under which the fees of employment agencies were specified. ${ }^{3}$ Mr. Justice

* Scholar-in-Residence, University of Virginia Law School. A.B. I9r8, LL.B. I921, LL.D. (hon.) I970, University of Idaho. Former chairman of the Section on Public Utility Law, American Bar Association. Member of the Idaho, New York, Virginia, and District of Columbia bars.

${ }^{1}$ Nebbia v. New York, 29r U.S. 502, 525, 537 (I934).

3 Tagg Bros. \& Moorhead v. United States, 280 U.S. 420 (r930), and Acker v. United States, 298 U.S. 426 (1936) (stockyard prices); Sunshine Anthracite Coal Co. v. Adkins, 3I0 U.S. 38I (I940) (maximum and minimum charges for bituminous coal).

${ }^{3}$ Olsen v. Nebraska ex rel. Western Reference \& Bond Ass'n, Inc., 313 U.S. 236 (I94I) (fees of em- 
Douglas, who wrote for a unanimous Court in the latter case, said, "We are not concerned, however, with the wisdom, need, or appropriateness of the legislation. Differences of opinion on that score suggest a choice which 'should be left where ... it was left by the Constitution-to the States and to Congress." "4

Actual seizure of the property of proprietary hospitals for governmental use might be deemed beyond the reach of executive authority. ${ }^{5}$ But if a health care commission were to be set up appropriately at either the state or federal level to resist further escalation of hospital charges, the Supreme Court could not be expected to lift a restraining hand. As much might be said of a steel or copper, or even automobile, commission. If, upon a modern presentation, the Court sustained state regulation of gasoline prices, some of its tart language in Williams v. Standard Oil $\mathrm{Co}^{6}$ would have to be masticated, but that suppression of price regulation was the product of an earlier dispensation and few lawyers would rely on it serenely in the r97os.

Why would regulation of the health care industry be analogous to the fixing of public utility rates and practices? Basically, because the business of health care is deeply and intimately affected with a public interest, because hospitals and like institutions have the power of exploitation in some measure, even though it is not frequently exercised, and because such instrumentalities carry on what is in some respects a natural monopoly. And, as has long been recognized as a matter of economics as well as law, when a necessity of life is provided by a monopoly or quasi-monopoly, effective regulation of that enterprise is required to protect the public interest.

Many hospital administrators may feel that their institutions are not naturally monopolistic, but in some respects they plainly are. When my surgeon said in 1952 that he "had to have a look" at my left lung, I raised no questions about the hospital in which my operation was to be performed, and, far from having done any bargaining as to prospective charges, I did not even know the cost of my hospital room until a bill was delivered.

The more-or-less monopolistic status of hospitals plainly will vary from community to community. If a particular institution is the only hospital within a radius of fifty to one hundred miles, it will have potential monopoly power, but if there are other hospitals in the same city and still more just down the highway, the competition it faces is real. That competition will, of course, ordinarily be at a higher level than mere determinations of charges for a specific service.

To be specific, the University of Virginia hospital in Charlottesville competes for tax dollars and for state-wide approval with the Medical College of Virginia hos-

\footnotetext{
ployment agencies), overruling Ribnik v. McBride, 277 U.S. 350 (1928), a similar case which came to the Court from New Jersey.

${ }_{313}$ U.S. at 246, quoting Ribnik v. McBride, 277 U.S. 350, 375 (dissenting opinion).

$\checkmark$ See Youngstown Sheet \& Tube Co. v. Sawyer, 343 U.S. 579 (2952) (the steel seizure decision).

${ }^{\circ} 278$ U.S. 235 (1929). See generally A. Priest, Princtples of Punlic Utility Regulation 6-io (1969).
} 
pital in Richmond, and it also competes with the smaller Martha Jefferson hospital in Charlottesville and with other institutions within and without the Commonwealth. To be sure, Martha Jefferson is a community hospital, and the University institution is a referral hospital. And the two institutions supplement and complement each other, for they perform distinguishable functions. But the person sent to one hospital or the other has small awareness of any competition between the establishments.

Charges made by the smaller Martha Jefferson hospital are often lower than those billed at the University, but those differences seem appropriate because the University hospital services are broader in over-all scope than those rendered at Martha Jefferson. And similar observations could be made about differences in hospital service charges in the same community, between communities, and between sections of the countryNew York City, for example, as against Biloxi, Mississippi.

The analogy between health care and public utility service is not exact, and many hospital executives may feel that they should not adopt the utility concept; but the final decision will not be theirs. New York has already begun the regulation of hospital charges, ${ }^{7}$ and other states will inevitably follow. Vox populi, made strident by sky-rocketing rates for health care, is declaring, "There ought to be a law!" And there will be-certainly at the state level and perhaps also in the form of Congressional enactment. Legislators, executives, and the health care industry plainly must be prepared to choose between regulatory control pursuant to the utility model and some alternative which might seem even less appealing.

The establishment of a uniform system of accounts might come first. And much time may pass before there can be full agreement as to particular items. General accounting principles, as such, may not present too much difficulty, and there certainly will be agreement that hospitals and their administrators must accept the goldfish-bowl life. The preparation of a set of guidelines comparable with the Separations Manual under which plant account, operating expenses, and operating revenues of telephone companies are allocated between interstate and intrastate service will require a vast expenditure of time and energy. Yet such a system will come, and it should produce a large measure of accounting uniformity.

Application of uniform standards for the purpose of determining the cost of health care service will be difficult. There presumably are no uniform cost standards because there are no uniform standards of patient care. Comparisons between hospitals $X$ and $Y$ located in the same city may be grossly invalid because the quality of patient care at Hospital $X$ towers above that provided at Hospital $Y$. The ratio of house officers to number of beds may be three times as high at $X$ as it is at $Y$. $X$ may provide twice the square feet per bed that are available at $Y$. $X$ may operate a cobalt unit, an emergency department, a unit for intensive care, and a renal

\footnotetext{
${ }^{\top}$ See N.Y. Pub. Health Law $\$$ 2800-o9 (McKinney Supp. I969); to NYCRR $\$$ 701.I-.4 (I969) (administrative regulations issued pursuant to $\$ \$ 2803$ ). See also N.Y. Soc. WeLfare LAw $\$ 365-a$ (McKinney Supp. I969). Passed in the 1969 regular session, $\$ 365-\mathrm{a}$ is one of a group of provisions designed to limit the drastic increase in New York public assistance expenditures. Litigation seeking to test the constitutionality of this legislation is in process, and significant precedents may well result.
} 
dialysis center, while $Y$ has none of them. Yet they all must be paid for through appropriate cost allocations. Standards of both cost and patient care must and will be evolved, however, through Blue Cross, Blue Shield, Medicare, Medicaid, and such institutions as the American Hospital Association.

Determination of health care charges will be inherently more difficult than the fixing of utility rates. For example, a kilowatt hour of electric energy is a kilowatt hour, and a therm of natural gas having prescribed characteristics is just that. In the interest of avoiding fine-pencil cost accounting, an electric utility may provide kilowatt hours both in New York City, where utility cable must be excavated by teaspoon, and in some small Westchester community served through a modest overhead distribution system and yet bill each of those kilowatt hours at the same rate. That is called "postage-stamp" pricing, and it does pragmatic justice. But a postage-stamp rate cannot be applied to health care. Thus simple appendectomies may carry different price tags at hospitals in the same community. And yet regulations must be set up under which appropriate price comparisons can be made.

Prevention of discrimination has been a vitally necessary aspect of utility regulation since that process began. Even exorbitant utility rates probably have generated less exasperation than discriminatory practices. Preferences granted to $A$ and denied to the similarly situated and equally deserving $B$ do violence to the American creed. Furthermore, they characteristically stir $B$ into action.

The Supreme Court said in 1947 that " $[\mathrm{t}]$ he principal evil at which the Interstate Commerce Act [the primordial regulatory statute in this country] was aimed was discrimination in its various manifestations."8 And the Texas Court of Civil Appeals observed in 1955, referring to the Commerce Act and the Texas Railroad Commission Act, "The primary purpose of both acts is to prevent discrimination." These adjurations express that allergy to the preferential which most citizens of the Republic would acknowledge, and they obviously will apply to the health care industry if the over-all precepts of utility regulation are imposed upon it.

There plainly can be no discrimination between patients as to quality of care. Distinctions predicated on race plainly are anathema; nor may hospitals provide Cadillac care for the affluent, put the upper middle classes in Buicks, and make the impoverished ride in Volkswagens. Nor should distinctions be made between the patient in the private room and one in the ward suffering from the same affliction. And such institutions should not apply one standard of care, or one schedule of charges, to the Blue Cross, Blue Shield, Medicare, or Medicaid patient and another to the equally deserving citizen who is wholly indigent or who appears on his own with viable checkbook in hand.

The certificate of public convenience and necessity has long been an essential reg-

\footnotetext{
${ }^{8} \mathrm{New}$ York v. United States, 33I U.S. 284, 296 (1947). See, e.g., $\$ 205(b)$ of the Federal Power Act, I6 U.S.C. $\$ 824 \mathrm{~d}(\mathrm{~b})$ (Ig64).

Humble Oil \& Refining Co. v. Texas \& Pac. Ry., 275 S.W.2d 824, 828 (Tex. Civ. App. 1955). See generally A. PrIEst, supra note 6, at 286-326.
} 
ulatory device. By what is the substantially uniform rule, no public utility may commence the construction of major facilities, begin operations or abandon them, enter new territory, exercise rights under a franchise, or issue securities, for example, until it has obtained from the agency having jurisdiction a certificate to the effect that the present or future public convenience and necessity require or will require the action contemplated. Most utilities are controlled monopolies (certainly to greater or lesser extents) and the certificate of public convenience and necessity, as granted, conditioned, denied, withdrawn, or modified, implements that control.

Mr. Justice Brandeis stated the predicate for certifying or licensing utility functions in his celebrated dissent (it clearly would have been the Court's majority opinion at any time since the late 1930s) in New State Ice Co. v. Liebmann:

The purpose of requiring [the certificate of public convenience and necessity] is to promote the public interest by preventing waste. Particularly in those businesses in which interest and depreciation charges on plant constitute a large element in the cost of production, experience has taught that the financial burdens incident to unnecessary duplication of facilities are likely to bring high rates and poor service.10

Should scarce, high-interest dollars be devoted to the construction of a forty-bed hospital in Smithville if Brownville, only twenty miles away, already has a one hundred-bed institution with facilities which can abundantly meet the needs of both communities? Smithville boosters who insist that their not-so-broad place in the road is entitled to its own hospital should receive slight consideration, even if the Smith of Smithville happens to be the chairman of the state Republican committee. After all, modern highways have made a trip of twenty miles no more than a negligible inconvenience. Should there be more than one cobalt unit or renal dialysis center in a particular community? Many hospital administrators have said "No." They would agree that the sharing of extraordinary health care facilities should be required through certification or licensing.

The basic purpose of public utility regulation is "to assure the furnishing of adequate service to all public utility patrons, without discrimination, and at the lowest reasonable rates consistent with the interests both of the public and the utilities." ${ }^{\text {"11 }}$ Key phrases consistently have been "just and reasonable," "without undue discrimination," and "in the public interest."

The public service commission, the milk board, the workmen's compensation commission have-and the prospective health care agency will have-only such powers as a legislature shall have conferred upon them, expressly or by fair implication. Judge E. Barrett Prettyman has said that the several administrative agencies "have the powers granted them by law, and no others." The agencies "are either making, carrying out, or interpreting law. Those are affirmative functions, but they are limited by the very terms of the affirmation."12

\footnotetext{
${ }^{10} 285$ U.S. 262, 282 (1932) (Brandeis, J., dissenting) (footnote omitted).

${ }^{11}$ Cassidy, Public Utility Regulation in California, CAL. Pub. Utrl. CODE I, 5 (West 1956).

${ }^{13}$ E. Prettraman, Trial by Agency 9 (I959).
} 
To speak somewhat generally, the orthodox making of public utility rates requires four basic determinations: (I) what are the enterprise's gross utility revenues under the rate structure examined; (2) what are its operating expenses, including maintenance, depreciation, and all taxes appropriately incurred to produce those gross revenues; (3) what utility property provides the service for which rates are charged and thus represents the base (called rate base) on which a return should be earned; and (4) what percentage figure (called rate of return) should be applied to the rate base to establish the return, or wages of capital, to which investors in the utility enterprise are reasonably entitled..$^{13}$

In formal rate proceedings, relevant data covering a "test period" of one year are examined. Both gross revenues and (at least in a great majority of the states) operating expenses will come directly from the utility's books and normally will not be questioned. Of course, if particular operating expenses are challenged as unreasonable, their appropriateness must be demonstrated. Operating expenses are deducted from gross revenues to arrive at utility income, again return on rate base. It will include interest on debt securities, dividends on stock, and additions to surplus. ${ }^{14}$

For the purposes of this article, it may suffice to say that rate base figures come directly from plant accounts in "original-cost" jurisdictions, but that commissions which examine the current "fair value" of utility properties weigh such criteria as "trended" original cost and reproduction or replacement data, together with original cost (except in Ohio, which is strictly a reproduction-cost-new-less-depreciation state). There are thirty-two "original-cost," and seventeen "fair-value," jurisdictions, with New York and New Jersey having a foot in either camp. ${ }^{15}$ Federal agencies apply the original-cost principle uniformly. The dichotomy of original cost versus fair value presumably will cause some regulatory agony until prices become stable. And few breaths will be held until that condition is attained.

Rate of return is a judgment figure. Cost of money is an important factor. So also are the requirements that the return to the equity owner "should be commensurate with returns on investments in other enterprises having corresponding risks" and "should be sufficient to assure confidence in the financial integrity of the enterprise, so as to maintain its credit and to attract capital."16 No utility is "guaranteed" revenues which will cover all of its capital costs. To the contrary, a utility has no more than an "opportunity" to earn the reasonable cost of conducting its business. The Supreme Court said flatly in 1942 that "regulation does not insure

\footnotetext{
${ }^{13}$ See Missouri ex rel. Southwestern Bell Tel. Co. v. Public Serv. Comm'n, 262 U.S. 276, 290-92 (r923) (Brandeis, J., dissenting). See also City of Cleveland v. Public Util. Comm'n, I64 Ohio St. 442, 443-44, I32 N.E.2d 216, 2I7 (1956). See generally A. Priest, stupra note 6, at 44-138.

14 A. PRIEST, supra note 6 , at 45-46.

${ }^{15} \mathrm{Id}$. at $153-55,156$. Iowa became an original-cost state after the preparation of the tabulations cited.

${ }^{16}$ FPC ४. Hope Natural Gas Co., 320 U.S. 59r, 603 (I944). See also Permian Basin Area Rate Cases, 390 U.S. 747, 791-92 (1968).
} 
that the business shall produce net revenues."17 Francis X. Welch has properly compared a utility's return allowance to "a fishing or hunting license with a limit on the catch."18 In a word, the utility is told that it may catch six bass or shoot four Canadian geese, but will be given no assurance that it will net one fish or knock off a single feather.

What the regulation of utilities characteristically entails may be indicated briefly. Utilities must not only obtain commission approval (either tacit or express) before changes in rates are permitted to become effective. They must accept and abide by reasonable standards and practices to make sure that their facilities will promote the safety, convenience, and best interests of ratepayers, employees, and the public generally. They must prepare and file annual and other reports disclosing their fiscal status and operating results and, in the process, must follow uniform systems of accounts promulgated by state tribunals and federal agencies. Utilities may issue evidences of indebtedness (bonds, debentures, or long-term bank notes) and "equity securities" (preferred and common stocks) only for specified purposes and after having obtained regulatory permission. They may not construct major facilities, enter new service areas, or exercise rights under franchises granted by municipalities until they obtain from the appropriate commission an appropriate certificate of public convenience and necessity. They may not abandon without commission consent any facilities which they have dedicated to the public service, and they must get regulatory approval before they transfer facilities to others. They are forbidden to discriminate unduly between persons, communities, or classes of service. They may not merge or consolidate with other utilities until the agency having jurisdiction gives the nod. They are, in the large and in many particulars, thoroughly regulated enterprises.

That language paints broadly. Certain commissions have ampler powers and higher standards than others, but the general picture is not far from accurate. Utilities are subject to constant surveillance, to searching investigation, and to the bright light of sometimes pitiless publicity in the service of over-all community interests.

Whether the rate-base/rate-of-return technique should be applied to the health care industry as a whole may be questioned, in part because proprietary, as operatedfor-profit, hospitals are fewer in number and lesser in over-all impact than the voluntary, nonprofit institutions.

As an alternative, the "financial requirements" technique for arriving at rates charged for regulated commodities or services has intrigued various regulators in this country, and it might well be considered for use in the health care industry, where only a small proportion of the dollars invested represent "other peoples' money," on which a return (the wages of capital) must be earned. Voluntary hos-

\footnotetext{
${ }^{17}$ FPC v. Natural Gas Pipeline Co., 315 U.S. 575, 590 (1942).

${ }^{18} \mathrm{~F}$. Welch, Cases and Text on Public Utility Regulation 478 (rev. ed. I968).
} 
pitals have financial requirements, to be sure, but since they need not pay dividends on stock or even, in many instances, interest on debt, rate-base and rate-of-return calculations seem inapplicable to them.

Commissioner Ralph T. Catterall of the Virginia State Corporation Commission has urged in several separate opinions that the question for determination in a rate proceeding was simply how much revenue would enable the utility concerned to attract new capital..$^{19}$ In his opinion in the recent Virginia Electric and Power Company case, Commissioner Catterall says:

If a company needs $X$ dollars to stay in business it has to get that number of dollars or cease to operate. For that very obvious reason, every judicial decision in this branch of the law declares that a utility must earn enough to attract capital. Since that law applies regardless of the rate base that the court favors, its pronouncement of that rule of law is a ruling that it makes no difference what rate base is used.

The amount of earnings necessary to attract capital is a question of fact that cannot be found with mathematical certainty because it involves a prediction. The so-called "cost of money" evidence in these cases is received in an effort to make a correct prediction. The hundreds of pages of that evidence in this case and in all other cases deal with percentages that are not percentages of any rate base. A decision that that kind of evidence is relevant amounts to a holding that the rate base is immaterial. ${ }^{20}$

The most widely discussed commission decision which frankly abandoned ratebase, rate-of-return findings was the Wisconsin Commission's opinion in City of Two Rivers v. Commonwealth Telephone Co. Here is that commission's statement of its rationale:

The rates which we shall prescribe in this proceeding are accordingly not arrived at by ascertaining what the level of them would have to be to afford any given percentage relationship between the net profit, or "return" thereunder, and the value of the utility property involved-whatever that value might be under the evidence before us. Nor are those rates arrived at by a modification of that method whereby something other than "present fair value" is adopted as the proper equivalent of a rate base. In other words, we have not substituted original cost, original investment, or either of them, after subtracting depreciation or depreciation reserve, for present fair value as constituting the proper equivalent of a rate base. The rates herein prescribed are arrived at without determining any rate base, and without determining any specific figure as constituting a "fair rate of return" on anything that may be claimed to be a proper rate base. The rates herein prescribed are estimated and intended to afford approximately an annual net profit of a determined number of dollars which we think it reasonable for the utility to enjoy from the operation of its business. ${ }^{21}$

${ }^{10}$ See, for an earlier explosion, his dissent in Chesapeake \& Potomac Tel. Co., 2I P.U.R.3d 239, 249-

53 (Va. Corp. Comm'n I957).

${ }_{20} 83$ P.U.R.3d 4I7, 419-20 (Va. Corp. Comm'n r970).

21 7o P.U.R.(n.s.) 5, to (Wis. Pub. Serv. Comm'n r947). 
On appeal, a Wisconsin circuit court reacted violently. The commission was reversed and paddled painfully. ${ }^{22}$ Wisconsin's Supreme Court promptly affirmed, observing that the commission was required to make specific findings of the "relevant facts and circumstances."23

The writer participated in a long freight-rates proceeding before Canada's then Board of Transport Commissioners in r949. ${ }^{24}$ All of the Canadian railroads were involved, including the Canadian Pacific Railway Company, for which the writer helped to present rate-base, rate-of-return, and cost-of-money testimony. In its decision the Board attached little significance to rate-base or rate-of-return evidence, but predicated Canadian Pacific's freight rates on that railroad's financial requirements: all operating expenses, including depreciation, maintenance, and taxes, fixed charges on debt securities, dividends of four per cent on preferred stock and five per cent on ordinary or common stock, plus an additional sum of $\$ 55,235,000$ for surplus, specifically for additions and betterments.

Despite official frowning on the "financial requirements" method in the United States, it may have possibilities for the determination of hospital charges. One of its virtues is that it can be applied to both proprietary and voluntary hospital facilities, with an allowance for interest charges as well as dividends (perhaps at a percentage of total equity) on the common stocks of for-profit hospitals. And of course it has the further virtue of being comparatively simple. It may be added that the Supreme Court will not concern itself with mere techniques or methods of regulation, as the recent and almost completely permissive Permian Basin ${ }^{25}$ decision so thoroughly demonstrates.

Shall health care charges be determined at the state or at the federal level? If the Congress is so inclined, a constitutional handle for the regulation of hospitals by a federal agency quite certainly can be found, ${ }^{26}$ but hospital service seems so patently intrastate in character that the Congress might be persuaded to leave the regulation of such service to the states. When a prostate gland is whacked out, neither gland nor patient is likely to move in interstate commerce, at lease for an extended while. And other hospital functioning seems basically and essentially local.

If a state agency fixes charges for hospital services which neither involve nor burden interstate commerce, the Supreme Court might well hold that instrumentalities of the United States which undertook to pay for those services would be required to pay in accordance with the schedule of charges established by such state

\footnotetext{
${ }^{29}$ Commonwealth Tel. Co. v. Public Serv. Comm'n, 7 I P.U.R.(n.s.) 65, 70 (Wis. Cir. Ct. I947).

${ }^{33}$ Commonwealth Tel. Co. v. Public Serv. Comm'n, 252 Wis. 48r, 484, 32 N.W.2d 247, 248 (1948).

${ }^{24}$ General Increase in Freight Rates, 64 Can. Ry. Cas. I, 6, II, 2I-22 (Bd. of Transport Comm'rs 1949); id. at 39 (Wardrope, Comm'r, dissenting).

${ }_{25}$ Permian Basin Area Rate Cases, 390 U.S. 747 (xg68).

${ }^{30}$ NLRB decisions holding the hospital labor market is interstate in character offer one point of departure for such a finding. See Butte Medical Properties, x68 N.L.R.B. No. 52 (1967). Voluntary hospitals are, however, exempted by statute. See National Labor Relations Act $\$ 2(2), 29$ U.S.C. $\$$ I52(2) (1964).
} 
commission. Thus in Penn Dairies, Inc. v. Milk Control Commission, ${ }^{27}$ the Court announced that those who contract to furnish supplies (in that instance milk sold for consumption at an Army camp) or render services to the federal government are not federal agencies and do not perform governmental functions. The Court said that "the mere fact that non-discriminatory taxation or regulation of the contractor imposes an increased economic burden on the government is no longer regarded as bringing the contractor within any implied immunity of the goverment from state taxation or regulation." 28

Utility regulation has most of the imperfections of our other major institutions. Some few state commissions are inadequately staffed and grimly pathetic. But most regulators are honest, decent, self-respecting servants of the public who do a generally excellent job. By and large, they keep their commitments, they implement their promises, and they throw no curve-balls. Over a period of some fifty years, the writer has been in strenuous controversies with regulators, but with only trifling exceptions has respected all of them and liked most of them. Regulation has worked, and this country has enjoyed better, and more reasonably priced, electric, natural gas, and communications services than other nations on the globe. ${ }^{20}$

It is not suggested that the regulation of health care become the responsibility of existing public utility commissions. With what must be rare exceptions, those agencies-most of them highly specialized-have no expertise in the health care field. ${ }^{30}$ Therefore new administrative tribunals must be organized. Commissioners presumably would be appointed by the governors of the several states. They should be named for comparatively long terms-ten years or more. And the new agencies must be given sufficient appropriations to enable them to set up competent, skilled, aggressive staffs. Regulation of health care charges and services will be of vast public consequence, and it is to be hoped that both commissioners and members of staffs will make such regulation their life-time careers.

Regulation of health care will be immensely difficult, but it plainly must be attempted. There seems to be no other feasible remedy for soaring hospital prices. Perhaps the public utility analogy is less than apt, but the only alternative seems to be government ownership and operation, for which a Thomas Jefferson Democrat has only the most dilute enthusiasm.

\footnotetext{
27318 U.S. 26 I (I943).

28 Id. at 269 .

${ }^{29}$ Arguably these services would have been no better, and possibly worse, in the absence of regulation.

${ }^{30}$ The Pennsylvania Insurance Commissioner already regulates Blue Cross and Blue Shield. See PA. Stat. Ann. tit 40, $\$ 75 \mathrm{I}$ et seq. (Supp. I97I).
} 